\title{
PENGEMBANGAN MEDIA VIDEO PEMBELAJARAN PADA ATLET TARUNG DERAJAT SATUAN LATIHAN ( SATLAT )
}

\author{
Riduan Saleh Lubis ${ }^{1}$, Sahat Siagian ${ }^{2}$, R.Mursid $^{3}$ \\ ${ }^{1}$ Sekolah Menengah Kejuruan Negeri 7 Medan, Sumatera Utara \\ ${ }^{2,3}$ Pascasarjana Universitas Negeri Medan \\ riduansalehlubis@gmail.com ${ }^{l}$
}

\begin{abstract}
Abstrak: Penelitian ini bertujuan untuk: (1) menghasilkan media video pembelajaran yang layak digunakan, mudah dipelajari dan dapat dipakai untuk pembelajaran individual (2) mengetahui efektifitas media video pembelajaran yang dihasilkan, dalam meningkatkan hasil latihan atlet Tarung Derajat Satuan Latihan ( Satlat ) Kampus II TPI Medan. Hasil penelitian menunjukkan; (1) uji ahli materi Tarung Derajat termasuk dalam kategori sangat baik (92,58\%), (2) uji ahli desain pembelajaran dalam penilaian dengan kategori baik (66,88\%), (3) uji ahli rekayasa perangkat lunak berada pada kategori baik (71,05\%), (4) uji coba perorangan berada pada kualifikasi baik (79,16\%), (5) uji coba kelompok kecil berada pada kualifikasi baik (78,84\%),(6) uji coba lapangan berada pada kualifikasi sangat baik (85,56\%). Hasil pengujian hipotesis membuktikan bahwa terdapat perbedaan yang signifikan antara hasil latihan atlet yang dibelajarkan dengan menggunakan media video pembelajaran dengan hasil latihan atlet yang dibelajarkan dengan menggunakan media pembelajaran konvensional. Hasil latihan atlet yang dibelajarkan dengan menggunakan media video pembelajaran adalah sebesar $67 \%$ dan lebih tinggi dari kelompok atlet yang dibelajarkan dengan menggunakan media pembelajaran konvensional,yaitu sebesar $59.50 \%$.
\end{abstract}

Kata Kunci: pengembangan media video pembelajaran, atlet tarung derajat

\begin{abstract}
This research is aimed to: (1) Generate qualified Interactive Learning Media, and it was fulfilling the requirement as a good medium of learning, (2) Assure the effectiveness of the generated teaching and learning video media to Increase the learning outcomes to treatmant result of atlet of Tarung Derajat Satuan Latihan ( Satlat ) Kampus II TPI Medan. The findings of the study were : (1) the quality of the developed instructional media viewed from the expert in Tarung Derajat is excellent (92.58\%), (2) the quality viewed from the expert in instructional design is good (66.88\%), (3) the quality viewed from the expert in media product good $(71.05 \%)$, (4) the one-to-one try out, from the observation of the three students, indicates that the product is good $(79.16 \%)$, the small group try-out, from the observation of nine students, indicates that the product is good (78.84\%), and the large group try out, from the observation of the thirty atlet, indicates that the product is excellent (85.56\%). The result of hypothesis test proves that the study results of the atlet taught using video instructional media treatment result and the conventional instructional shows a significant difference. It can be concluded that the number shown by the study group using video instructional media treatment result is much larger than that of using convensional. It is further verified that the percentage of effectiveness by using video instructional media treatment result is $67 \%$, while using convensional instructional as media display $59.50 \%$.
\end{abstract}

Keywords: development of Video Instructional Media, atlet tarung derajat

\section{PENDAHULUAN}

Olahraga mempunyai arti dan nilai karena berada dalam konteks semua aspek kehidupan sosial seperti politik, ekonomi, agama, sosial, pendidikan, dan budaya. Kehidupan sosial ini berpotensi menentukan perkembangan jasmani, olahraga, dan rekreasi. Olahraga selain merupakan bagian dari kebudayaan manusia, juga merupakan bagian dari hidup manusia, seperti melatih ketangkasan fisik (Sumardianto, 2000:1). Olahraga juga memainkan perannya yang amat penting dalam pembinaan manusia seutuhnya (Sumardianto, 2000:106).

Pendidikan adalah suatu usaha sadar dalam menyiapkan peserta didik melalui kegiatan bimbingan, pengajaran dan latihan bagi kehidupan yang akan dating hal ini merupakan tanggung jawab bersama antara pemerintah, anggota masyarakat dan orang tua. Untuk mencapai keberhasilan ini, perlu dukungan dan partisipasi aktif yang bersifat terus menerus dari semua pihak. Pembangunan di bidang pendidikan adalah upaya yang sangat menentukan dalam rangka meningkatkan 
kualitas manusia. Salah satu upaya itu adalah mewujudkan bentuk manusia Indonesia yang sehat, kuat, terampil dan bermoral melalui pendidikan jasmani.

Pendidikan jasmani adalah proses pendidikan yang diarahkan untuk mendorong, membimbing, mengembangkan, dan membina kemampuan jasmaniah dan rohaniah serta kesehatan siswa dan lingkungan hidupnya agar tumbuh dan berkembang secara harmonis dan optimal sehingga mampu melaksanakan tugas bagi dirinya dan untuk pembangunan bangsa. Tujuan pendidikan jasmani di sekolah adalah untuk membantu peserta didik meningkatkan keterampilan gerak, pemahaman kognitif, dan sifat positif terhadap aktivitas jasmani yang kelak akan menjadi manusia yang sehat jasmani dan rohani serta berkepribadian mantap.

Salah satu masalah utama dalam pendidikan jasmani di Indonesia adalah belum efektifnya pengajaran pendidikan jasmani di sekolah-sekolah. Kondisi kualitas pengajaran pendidikan jasmani yang memprihatinkan mulai dari jenjang sekolah dasar, sekolah lanjutan dan bahkan perguruan tinggi telah dikemukakan dan ditelaah dalam berbagai forum oleh beberapa pengamat pendidikan jasmani dan olahraga. Kondisi ini disebabkan oleh beberapa faktor, diantaranya ialah terbatasnya kemampuan guru pendidikan jasmani dan terbatasnya sumbersumber yang digunakan untuk mendukung proses pengajaran pendidikan jasmani.

Gaya mengajar yang dilakukan oleh guru dalam praktek pendidikan jasmani cenderung tradisional. Model metode pembelajaran berpusat pada guru (teacher centered) dimana para siswa melakukan latihan fisik berdasarkan perintah yang ditentukan oleh guru. Latihanlatihan tersebut hampir tidak pernah dilakukan oleh siswa sesuai dengan inisiatif sendiri (student centered). Guru pendidikan jasmani tradisional cenderung menekankan pada penguasaan keterampilan cabang olahraga. Dalam pendekatan ini, guru menentukan tugastugas ajarnya kepada siswa melalui kegiatan fisik tak bedanya seperti melatih suatu cabang olahraga. Perkembangan teknologi komunikasi dan informsi (TIK) yang sangat cepat juga telah mempengaruhi seluruh aspek kehidupan masyarakat dan menciptakan kultur baru bagi semua orang di seluruh dunia. Dunia pendidikan pun tak luput dari pengaruhnya. Pengaruh yang paling utama dalam hal penggunaan teknologi komunikasi dan informasi dalam pembelajaran terkait dengan mata pelajaran di sekolah adalah bergesernya paradigma pembelajaran dari teacher oriented menuju student oriented.

Gerlach dan Elly (1980: 244) mengungkapkan bahwa "media is a channel of communication. Derived from the latin word for "beetween', the term refers to anything that carries information between a source and a receiver". Dari pengertian di atas dapat kita garis bawahi bahwa media adalah perantara dari sumber informasi ke penerima informasi, contohnya video, televisi, computer dan lain sebagainya. Alat-alat tersebut merupakan media manakala digunakan untuk menyalurkan informasi yang akan disampaikan. Sanjaya (2012:34) menegaskan bahwa media bukan hanya sekedar informasi beserta alatnya, akan tetapi juga proses mempelajarinya, sebab informasi atau pesan yang hanya diketahui hasil pemberitahuan orang lain, tidak akan menjadikan informasi tersebut menjadi bermakna dalam hidupnya. Dengan demikian sebagai perantara media juga meliputi berbagai pengalaman untuk memahami materi pelajaran.

Selanjutnya, Gerlach dan Ely (1980: 54) menyatakan "A medium, conceived is any person, material or even that establish condition which enable the learner to acquire knowledge, skill and attitude." Menurut Gerlach secara umum media (pembelajaran) itu meliputi orang, bahan, peralatan, atau kegiatan yang menciptakan kondisi yang memungkinkan siswa memperoleh pengetahuan, keterampilan, dan sikap. Jadi dalam pengertian ini media pembelajaran bukan hanya terpaku pada alat perantara seperti $\mathrm{TV}$, radio, slide, bahan cetakan tetapi meliputi orang atau manusia sebagai sumber belajar. Sependapat dengan pandangan Gerlach, Gagne (1983:49) juga menyatakan bahwa media pembelajaran adalah berbagai komponen yang ada dalam lingkungan siswa yang dapat merangsangnya untuk belajar. Lingkungan itu sendiri cukup luas seperti laboratorium multimedia, perpustakaan, atau mungkin apotek hidup yang terdapat di halaman sekolah dan lain sebagainya. Novian (2005:64) menyatakan bahwa semakin banyak tujuan pembelajaran yang bisa dibantu dengan media pembelajaran maka semakin baiklah proses belajar mengajar. 
Media merupakan alat untuk menyampaikan informasi atau pesan dari suatu tempat ke tempat lain. Menurut I Santyasa (dalam Sahid 2012), proses pembelajaran mengandung lima komponen, yaitu guru (komunikator), bahan pembelajaran, media pembelajaran, siswa (komunikan) dan tujuan pembelajaran. Senada dengan pendapat di atas menurut E.Shannon dan weaver (dalam Cangara 2009: 22 ), dua orang insinyur listrik menyatakan bahwa terjadinya proses komunikasi memerlukan limaunsur yang mendukungnya yaitu pengirim, transmitter, signal, penerima dan tujuan.

Pemanfaatan teknologi informasi sebagai media pembelajaran dapat melalui pemanfaatan penggunaan VCD sebagai media Pembelajaran. Diharapkan dengan pemanfaatan media ini dapat merangsang pikiran, perasaan, minat, serta perhatian peserta didik sedemikan rupa sehingga proses pembelajaran dapat terjadi. Dalam Kamus Umum Bahasa Indonesia karya Poerwadarminta (2002:473), bahwa pengembangan adalah perbuatan menjadikan bertambah, berubah sempurna (pikiran, pengetahuan dan sebagainya). Istilah media, bentuk jamak dari perantara (medium), merupakan sarana komunikasi. Istilah ini merujuk pada apa saja yang membawa informasi antara sebuah sumber dan sebuah penerima. Enam kategori dasar media adalah teks, audio, visual, video, perekayasa (manipulative), dan orang - orang. Tujuan dari media adalah untuk memudahkan komunikasi dan belajar (Smaldino, 2011:7). Dari Olson (dalam Miarso, 2009:457) mendefinisikan medium sebagai teknologi untuk menyajikan, merekam, membagi, dan mendistribusikann simbol dengan melalui rangsangan indra tertentu, disertai penstrukturan informasi. Sedangkan menurut Aqib (2010:58) media pengajaran diartikan sebagai segala sesuatu yang dapat digunakan untuk menyalurkan pesan (message), merangsang pikiran, perasaan, perhatian, dan kemauan siswa sehingga dapat mendorong proses belajar.

Dipilihnya media video pembelajaran mata pelajaran Tarung Derajat atas dasar pertimbangan: (a) dalam memenuhi kebutuhan belajar siswa materi teknik dasar Tarung Derajat, (b) dapat digunakan guru sebagai sarana strategi dalam proses pembelajaran, dan (c) dapat digunakan siswa belajar secara mandiri.

Kegiatan olahraga yang dilakukan secara baik dan benar memiliki dampak positif dalam perkembangan siswa baik di sekolah maupun di lingkungan masyarakat. Karena kegiatan olahraga selain memberi manfaat kesehatan fisik juga dapat meningkatkan kemampuan berpikir dan sosialisasi siswa di berbagai bidang, salah satunya adalah dengan cabang olahraga Tarung Derajat.

Ketertarikan penulis untuk melakukan penelitian ini berawal dari pengamatan di lapangan saat peneliti melakukan Latihan Tarung Derajat di Satlat Kampus II TPI Medan, dimana atlet sedang mengikui latihan Tarung Derajat, peneliti melihat sebagian besar atlet kurang tertarik untuk mendengarkan penyampaian teori dan melakukan praktik latihan ini. Ada yang menganggap latihan ini sudah sering mereka lakukan sehingga tidak perlu lagi mendengarkan materi yang disampaikan pelatih, sebagian lagi yang biasa di dominasi atlet perempuan menganggap latihan ini sulit dilakukan, selain itu mereka juga takut dengan materi yang digunakan karena sakit jika terkena badan. Sehingga dibutuhkan inovasi dan modifikasi untuk membuat atlet lebih tertarik untuk mendengarkan dan menyimak materi yang disampaikan pelatih. Saat peneliti mengamati jalannya proses latihan terlihat sikap acuh pada atlet yang menganggap bahwa latihan Tarung Derajat sudah sering mereka lakukan sehingga mereka tidak berminat mendengarkan penjelasan pelatih lagi. Cara melakukan tendangan pun sering sekali tidak menggunakan teknik dasar yang benar, mereka hanya sekedar ingin menendang sesuka hatinya agar terlihat lebih perkasa. Ditambah lagi paradigma yang telah berubah yakni latihan Tarung Derajat yang berkembang sekarang yang penting anak sudah mau bergerak dan gembira. Hal itu memberikan ide kepada penulis untuk memodifikasi media pembelajaran latihan tarung Derajat agar atlet lebih tertarik mengikuti latihan dan serius mendengarkan penjelasan pelatih sehingga saat melakukan praktik mereka bisa dengan benar melakukannya.

Jika diamati lebih cermat lagi, pada mulanya media pembelajaran hanyalah dianggap sebagai alat untuk membantu guru dalam kegiatan mengajar. Alat bantu itu 
dimaksudkan untuk memberikan pengalaman lebih konkret, memotivasi, serta mempertinggi daya serap dan daya ingat siswa dalam belajar. Seiring berkembangnya teknologi, muncullah berbagai macam bentuk bahan ajar cetak, lalu merabah ke bahan ajar audio, hingga bahan ajar audiovideo serta bahan ajar interaktif dengan komputer.

Sekitar pertengahan abad-20 usaha pemanfaatan alat visual mulai dilengkapi dengan peralatan audio. Dari hal ini, maka lahirlah peralatan audio visual pembelajaran. Usaha-usaha untuk membuat pelajaran abstrak menjadi lebih konkret dan terus dilakukan. Pada tahun 1960-an, para ahli mulai memperhatikan siswa sebagai komponen utama dalam kegiatan pembelajaran.

Pada saat itu teori Behaviorisme dari BF.Skinner mulai mempengaruhi penggunaan media dalam kegiataan pembelajaran. Produk media pembelajaran yang terkenal adalah diciptakannya Mesin Pengajar dan Pembelajaran Terprogram. Pada tahun 1965-70, pendekatan sistem mulai menampakkan pengaruhnya dalam dunia pendidikan dan pengajaran. Pendekatan sistem ini mendorong digunakannya media sebagai bagian integral dalam proses pembelajaran.

Hingga saat ini, masih ada anggapan bahwa untuk belajar, gurulah yang mendatangi rumah atau kantor. Guru masuk ke ruangan menyajikan materi pembelajaran, membagi pengalaman atau menginformasikan sesuatu. Anggapan itu tidak sepenuhnya benar karena belajar dapat dilakukan dimana saja dan melalui beberapa cara antara lain melalui : televisi, video cassette, video compact disc atau computer. Walaupun tersedia beragam sumber belajar, kita berhak memilih informasi mana yang tepat untuk masing-masing individu. Setiap individu dapat memilih cara belajar dan menyesuaikan diri dengan tipe audio, visual atau keduanya.

Sebuah format media merupakan bentuk fisik yang di dalamnya pesan disertakan dan ditampilkan. Format media mencakup, sebagai misal, papan tulis penanda (visual dan teks), slide powerpoint (teks dan visual), CD (suara dan musik), DVD (video), dan multimedia komputer (audio, teks, dan video). Masing - masing memiiki kelebihan dan keterbatasan yang berbeda - beda dalam hal jenis pesan yang dapat direkam dan ditampilkan. Istilah pembelajaran digunakan untuk menunjukkan usaha pendidikan yang dilaksanakan secara sengaja, dengan tujuan yang ditetapkan terlebih dahulu sebelum proes dilaksanakan, serta yang pelaksanaannya terkendali. Perlu ditegaskan bahwa dalam proses pendidikan sering kali seseorang belajar tanpa disengaja, tanpa tahu tujuannya terlebih dahulu, dan tidak selalu terkendalikan baik dalam artian isi, waktu, proses, maupun hasilnya.

Tujuan dalam pengembangan ini adalah: (1) Menghasilkan media video pembelajaran yang berkualitas dan layak dijadikan acuan bagi atlet Tarung Derajat Satuan Latihan Satlat Kampus II TPI Medan dan dapat dipergunakan secara individu. (2) Untuk mengetahui keefektifan pengembangan media video pembelajaran pada atlet Tarung Derajat Satlat Kampus II TPI Medan.

\section{METODE}

Penelitian ini dilaksanakan di Satuan Latihan (Satlat) Kampus II Taman Pendidikan Islam (TPI ) Medan. Model pengembangan yang dipakai merupakan adaptasi dari model pengembangan Borg \& Gall (1983:772) dan untuk mengembangkan rencana dan memvalidasi produk dalam pengembangan video pembelajaran dipadukan dengan model pengembangan pembelajaran Dick \& Carey (2005:1). Adapun langkah - langkah dari tahapan pengembangannya adalah sebagai berikut: (1) Melakukan penelitian pendahuluan, (2) Pembuatan desain software, yang meliputi: Pembuatan naskah, pembuatan storyboard, pembuatan flowchart view, (3) Pengumpulan bahan, yang meliputi: Pembuatan dan pengumpulan gambar (image) dan animasi, perekaman dan pengumpulan audio, mengubah capture dan me-loging bahan hasil shooting pada program premiere ke dalam format avi, editing (image, text, sound effect, music, and animations), mengembangkan dan membuat media video pembelajaran, burning ke media VCD, (4) Review dan uji coba produk, (5) Uji keefektifan produk.

Data yang diperoleh disesuaikan dengan tujuan dan desain pengembangan yang digunakan, maka jenis data yang dikumpulkan dalam pengembangan ini adalah data kuantitatif sebagai data pokok, yang terkumpul melalui angket dengan skala penilaian 1 sampai 5 (1: 
sangat kurang, 2: kurang baik, 3: sedang, 4: baik, dan 5: sangat baik). Data kuantitatif melalui: (1) penilaian ahli materi, (2) penilaian ahli desain pembelajaran, (3) penilaian ahli video dan desain grafis, dan (4) penilaian siswa. Kemudian para responden akan memberi angka penilaian pada setiap butir angket berdasarkan kriteria yang telah ditetapkan. Selain itu jenis data yang dikumpulkan adalah data kualitatif berupa uraian saran dan masukan tertulis oleh responden sebagai data tambahan, yakni pertanyaan dan hasil observasi.

Dengan dasar tersebut maka pendekatan dalam tahap ini menggunakan pendekatan kualitatif dan kuantitatif. Pendekatan kualitatif digunakan untuk mengungkap tujuan yang pertama menggunakan metode observasi, sedangkan pendekatan kuantitatif digunakan untuk mengungkapkan tujuan yang kedua melalui tes penampilan dan tes hasil belajar. Untuk melihat keefektifan media video pembelajaran, maka pengujian dilakukan dengan eksperimen, yaitu membandingkan efektifitas media video pembelajaran dengan media konvensional (buku teks).

\section{Tahap Uji Coba Produk}

Uji coba dimaksudkan untuk mengumpulkan data dalam rangka evaluasi formatif yang dijadikan dasar dalam menetapkan apakah produk tersebut telah benar- benar layak digunakan dan menarik. Kegiatan yang dilakukan antara lain :

\section{Desain Uji Coba}

Adapun tahapan dari desain uji coba sebagai berikut :
a. Validasi ahli materi Tarung Derajat
b. Validasi ahli media video pembelajaran
c. Analisis konseptual
d. Revisi produk tahap I, berdasarkan penilaian yang berupa masukan, kritik atau saran dari 2 ahli materi dan 3 ahli media, 2 ahli desain instruksional untuk di lakukan perbaikan.
e. Uji coba terhadap siswa ( satu- satu/ perorang/ kelompok kecil ). Penilaian ini berdasarkan angket yang telah diisi oleh 3 siswa ( uji satu- satu ) dan 9 orang siswa ( uji coba kelompok kecil )
f. Analisis konseptual dan produk
g. Revisi produk tahap II

h. Uji coba lapangan terhadap siswa

i. Penilaian mengenai daya tarik dan kelayakan produk

j. Analisis empirik tahap III

k. Revisi kecil

1. Penilaian mengenai daya tarik dan kelayakan produk

m. Analisis empirik tahap IV

n. Revisi kecil

o. Uji efektivitas produk

\section{Teknik Analisis Data}

Analisis data dalam penelitian ini menggunakan teknik analisis kuantitatif. Sebelum dilakukan uji hipotesis, terlebih dahulu dilakukan persyaratan yaitu uji normalitas dan uji homogenitas. Uji normalitas dilakukan untuk mengetahui apakah skor variabel yang diteliti berasal dari populasi yang berdistribusi normal. Untuk mengetahui hal ini dilakukan dengan menggunakan Uji Chi Kuadrat sebagai berikut (Sugiyono, 2007):

$$
X^{2}=\sum \frac{(f o-f h)}{f h}
$$

Keterangan:

$\mathrm{X}^{2}=$ chi kuadrat yang dihitung

fo $=$ frekuensi observasi

fh $=$ frekuensi harapan

Gejala yang diamati berdistribusi normal jika $\mathrm{X}^{2}{ }_{\text {hitung }}<\mathrm{X}_{\text {tabel }}^{2}$ pada taraf signifikansi 0,05.

Untuk menguji homogenitas data, digunakan Uji Kesamaan dua varians. Dalam hal ini pengujian kesamaan variabs kedua populasi pada data hasil belajar sebagai berikut: $\mathrm{H}_{0} ; \mathrm{a}_{1}^{2}=\mathrm{a}_{2}^{2}$, dan

$\mathrm{Ha} ; \mathrm{a}_{1}^{2}=\mathrm{a}_{2}^{2}$

Dilakukan uji dua pihak dengan taraf signifikansi 0,05 ; hipotesis di atas diuji dengan rumus statistika:

$$
F=\frac{\text { Varians terbesar }}{\text { Varians terkecil }}
$$

Kriteria pengujian hipotesis:

$\mathrm{H}_{0}$ diterima jika $\mathrm{F} \leq \mathrm{F}(\mathrm{V} 1, \mathrm{~V} 2)$ dan $\mathrm{H}_{0}$ ditolak jika $F \geq F(V 1, V 2)$.

Untuk melihat apakah ada perbedaan yang signifikan antara hasil belajar dengan penggunaan media video pembelajaran dan media konvensional maka dilakukan Uji hipotesis dengan uji t, sebagai berikut: 
$t_{\text {hitung }}=\frac{\overline{x_{1}}-\overline{x_{2}}}{S D \sqrt{\frac{1}{n_{1}}+\frac{1}{n_{2}}}}$

Dengan $S D=\sqrt{\frac{\left(n_{1}-1\right) S_{1}{ }^{2}+\left(n_{2}-1\right) S_{2}{ }^{2}}{n_{1}+n_{2}-2}}$

Dengan $\mathrm{db}=\mathrm{n}_{1}+\mathrm{n}_{2}-2$

Keterangan :

$x_{1}=$ rata - rata skor kelas eksperimen

$x_{2}=$ rata - rata skor kelas kontrol

$\mathrm{n}_{1} \quad=$ jumlah sampel kelas eksperimen

$\mathrm{n}_{2} \quad=$ jumlah sampel kelas control

\section{HASIL DAN PEMBAHASAN}

\section{1) Analisis Data Hasil Evaluasi Ahli Materi}

$\mathrm{S}_{1}{ }^{2}=$ varians pada kelas eksperimen

$\mathrm{S}_{2}{ }^{2} \quad$ = varians pada kelas kontrol

$\mathrm{SD}=$ standar deviasi gabungan

Kriteria korelasi yang diperoleh dikatakan signifikan (hipotesis diterima) jika harga $t_{\text {hitung }}>$ $\mathrm{t}_{\text {tabel }}$ pada taraf signifikansi 0,05 .

Untuk melihat keefektifan media video pembelajaran yang dieksperimenkan digunakan rumus sebagai berikut (Sugiyono, 2007)

$X=\frac{\text { Jumlah } \text { Skor yang diperoleh }}{\text { Jumlah } \text { Skor seluruh item }} \times 100 \%$

Tabel 1. Persentase Rata-Rata Hasil Penilaian Terhadap Media Video Pembelajaran Oleh Ahli Materi

\begin{tabular}{|c|l|c|c|}
\hline No & \multicolumn{1}{|c|}{ Kategorisasi } & Persentase Rata-rata & Kriteria \\
\hline 1 & Aspek materi pembelajaran & $88,75 \%$ & Sangat Baik \\
\hline 2 & Aspek strategi pembelajaran & $94,00 \%$ & Sangat Baik \\
\hline 3 & $\begin{array}{l}\text { Aspek sistem penyampaian } \\
\text { pembelajaran }\end{array}$ & $95,00 \%$ & Sangat Baik \\
\hline \multicolumn{2}{|r|}{ Rata-rata } & $\mathbf{9 2 , 5 8 \%}$ & Sangat Baik \\
\hline
\end{tabular}

Dari tabel 1 diatas, dapat dilihat bahwa ahli materi menilai media video pembelajaran berdasarkan tiga aspek, yaitu kualitas materi pembelajaran, kualitas strategi pembelajaran, dan kualitas sistem penyampaian pembelajaran. Penilaian terhadap setiap aspek menunjukkan persentase rata-rata penilaian masing-masing $88,75 \%$ pada aspek kualitas materi pembelajaran, terhadap aspek kualitas strategi pembelajaran skor penilaian dari ahli materi adalah 94,00\% sedangkan pada aspek sistem penyampaian pembelajaran ahli materi memberikan penilaian dengan skor $95,00 \%$. Berdasarkan penilaian tersebut secara keseluruhan media video pembelajaran termasuk dalam kategori sangat baik. Oleh karenanya media video pembelajaran dapat memenuhi tuntutan kebutuhan pembelajaran.

\section{2) Analisis Data Hasil Evaluasi Ahli Desain Pembelajaran}

Tabel 2. Persentase Rata-Rata Hasil Penilaian Terhadap Media Video Pembelajaran Oleh Ahli Desain Pembelajaran

\begin{tabular}{|c|l|c|c|}
\hline No & \multicolumn{1}{|c|}{ Kategorisasi } & Persentase Rata-rata & Kriteria \\
\hline 1 & Kualitas desain pembelajaran & $70,00 \%$ & Baik \\
\hline 2 & Kualitas desain informasi & $72,50 \%$ & Baik \\
\hline 3 & Kualitas desain interaksi & $65,00 \%$ & Baik \\
\hline 4 & Kualitas Desain Presentasi & $60,00 \%$ & Sedang \\
\hline \multicolumn{2}{r|}{ Rata-rata } & $\mathbf{6 6 , 8 8 \%}$ & Baik \\
\hline
\end{tabular}

Penilaian ahli desain pembelajaran terhadap aspek kualitas desain pembelajaran menunjukkan persentase rata-rata $70,00 \%$ termasuk dalam kategori "Baik", yang berarti bahwa penampilan fisik media video pembelajaran mempunyai daya fungsional bagi peningkatan motivasi belajar peserta didik. Penilaian ahli desain pembelajaran terhadap 
aspek kualitas desain informasi menunjukkan persentase rata-rata $72,50 \%$ termasuk kategori "Baik", yang berarti informasi media video pembelajaran dapat memberikan kemudahan bagi peserta didik untuk memperoleh informasi yang diinginkan.

Penilaian ahli desain pembelajaran terhadap aspek kualitas desain interaksi menunjukkan persentase rata-rata $65,00 \%$ termasuk kategori baik yang berarti pengaturan isi pembelajaran memperhatikan aspek interaksi antara peserta didik dengan pembelajaran sehingga dapat tercipta suatu kondisi yang mampu memfasilitasi belajar. Persentase ratarata pada aspek desain presentasi adalah $60,00 \%$ termasuk kategori "Sedang" yang berarti presentasi dari media video yang dikembangkan memiliki tampilan yang cukup menarik untuk dapat menimbulkan rasa ketertarikan atlet untuk melakukan pembelajaran.

\section{3) Analisis Data Hasil Evaluasi Ahli Media Dan Desain Grafis}

Tabel 3. Persentase Rata-Rata Hasil Penilaian Terhadap Media Video Pembelajaran Oleh Ahli Media dan Desain Grafis.

\begin{tabular}{|c|l|c|c|}
\hline No & \multicolumn{1}{|c|}{ Kategorisasi } & Persentase Rata-Rata & Kriteria \\
\hline 1 & Pemprograman & $75,00 \%$ & Baik \\
\hline 2 & Kualitas tampilan & $67,10 \%$ & Baik \\
\hline \multicolumn{2}{|c|}{ Rata-rata } & $\mathbf{7 1 , 0 5 \%}$ & Baik \\
\hline
\end{tabular}

Penilaian ahli media dan desain grafis terhadap aspek pemrograman menunjukkan persentase rata-rata $75,00 \%$ termasuk dalam kategori "Baik". Ini berarti bahwa program perangkat lunak pada media video pembelajaran berfungsi dengan baik bagi peserta didik dalam hal memberi kemudahan dalam mendapatkan informasi yang diinginkan. Penilaian ahli media dan desain grafis terhadap aspek pemrograman menunjukkan persentase rata-rata $75,00 \%$ termasuk dalam kategori "Baik". Hal ini berarti bahwa media video pembelajaran mampu menciptakan kondisi pembelajaran mandiri dan dapat memberikan motivasi pembelajaran.

\section{4) Analisis Data Hasil Uji Coba Tahap II Uji Coba Perorangan}

Tabel 4. Persentase Rata-Rata Hasil Penilaian Terhadap Media Video Pembelajaran Pada Uji Coba perorangan

\begin{tabular}{|c|c|c|c|}
\hline No & Kategorisasi & Persentase rata-rata & Kriteria \\
\hline 1 & Aspek kualitas materi pembelajaran & $78,34 \%$ & Baik \\
\hline 2 & Aspek kualitas teknis/tampilan & $79,97 \%$ & Baik \\
\hline \multicolumn{2}{|c|}{ Rata-rata } & $\mathbf{7 9 , 1 6 \%}$ & Baik \\
\hline
\end{tabular}

Persentase rara-rata hasil penilaian media pembelajaran interaktif pada uji coba perorangan yang dilakukan pada 3 orang atlet dengan kemampuan, 1 orang atlet dengan prestasi belajar tinggi, 1 orang atlet dengan prestasi belajar sedang, dan 1 orang atlet dengan prestasi belajar rendah

\section{5) Analisis Data Hasil Uji Coba Tahap III}

Tabel 5. berikut menunjukkan persentase rata-rata dari hasil penilaian terhadap media video pembelajaran pada uji coba kelompok kecil di Satlat Kampus II TPI Medan terhadap aspek kualitas materi pembelajaran adalah sebesar $78,33 \%$ dan aspek kualitas teknis/tampilan sebesar $79,35 \%$ dan masing-masing termasuk kategori baik 
Tabel 5. Persentase Rata-Rata Hasil Penilaian Terhadap Media Video Pembelajaran Pada Uji Coba Kelompok Kecil

\begin{tabular}{|c|c|c|c|}
\hline No & Kategorisasi & Persentase rata-rata & Kriteria \\
\hline 1 & Aspek kualitas materi pembelajaran & $78,33 \%$ & Baik \\
\hline 2 & Aspek kualitas teknis/tampilan & $79,35 \%$ & Baik \\
\hline \multicolumn{2}{|c|}{ Rata-rata } & $\mathbf{7 8 , 8 4 \%}$ & Baik \\
\hline
\end{tabular}

\section{6) Analisis Data Hasil Uji Coba Tahap IV Uji Coba Lapangan}

Tabel 6. Persentase Rata-Rata Hasil Penilaian Terhadap Media Video Pembelajaran Pada Uji Coba Lapangan di Satlat Kampus II TPI Medan

\begin{tabular}{|c|l|c|c|}
\hline No & Kategorisasi & Persentase rata-rata & Kriteria \\
\hline 1 & Aspek kualitas materi pembelajaran & $85,25 \%$ & Sangat Baik \\
\hline 2 & Aspek kualitas teknis/tampilan & $85,86 \%$ & Sangat Baik \\
\hline \multicolumn{2}{r|}{ Rata-rata } & $\mathbf{8 5 , 5 6 \%}$ & Sangat Baik \\
\hline
\end{tabular}

Tabel 6. menunjukkan persentase rata-rata hasil penilaian terhadap media video pembelajaran pada uji coba lapangan di Satlat Kampus II TPI Medan yaitu terhadap aspek kualitas materi pembelajaran sebesar $85,25 \%$ dan aspek kualitas teknis/tampilan sebesar $85,86 \%$ dan masing-masing termasuk kategori sangat baik.

\section{HASIL PENELITIAN UJI EFEKTIFITAS PRODUK}

\section{Deskripsi Data Penelitian}

\section{a. Analisis Hasil Data Penelitian}

Berdasarkan penelitian maka diperoleh hasil test awal (pre-test) dan test akhir (post-test) untuk kedua kelompok sampel yaitu masingmasing kelompok eksperimen dan kontrol berjumlah 15 orang atlet. Seletah itu, dilakukan perhitungan sehingga diperoleh rata-rata pretest, post-test, dan simpangan baku seperti pada tabel 4.40 Di bawah ini.

Tabel 7. Rata-rata dan Simpangan Baku

\begin{tabular}{|c|c|c|c|c|c|c|c|}
\hline \multicolumn{3}{|c|}{ Kelas eksperimen } & \multicolumn{4}{c|}{ Kelas Kontrol } \\
\hline \multicolumn{2}{|c|}{ Pre-Test } & \multicolumn{2}{c|}{ Post-Test } & \multicolumn{2}{c|}{ Pre-Test } & \multicolumn{2}{c|}{ Post-Test } \\
\hline$X$ & $\mathrm{~S}$ & $X$ & $\mathrm{~S}$ & $X$ & $\mathrm{~S}$ & $X$ & $\mathrm{~S}$ \\
\hline 12,73 & 1,49 & 26,80 & 1,21 & 13,13 & 1,30 & 23,80 & 1,37 \\
\hline
\end{tabular}

Berdasarkan Tabel 7. Diperoleh nilai rata-rata nilai pre-test kelas eksperimen sebesar 12,73 dengan nilai tertinggi 15 dan nilai terendah 10 serta simpangan baku 1,49 sedangkan untuk rata-rata nilai post-test sebesar 26,80 dengan nilai tertinggi 28 dan nilai terendah 25 serta simpangan baku 1,21. Ratarata nilai pre-test kelas kontrol sebesar 13,13 dengan nilai tertinggi 15 dan nilai terendah 11 serta simpangan baku 1,30 sedangkan untuk rata-rata nilai post-test 23,80 dengan nilai tertinggi 26 dan nilai terendah 22 serta simpangan baku 1,37.

\section{Uji Persyaratan Analisis Data a. Uji Normalitas Data}

Dari hasil perhitungan data pre-test dan post-test untuk kelas eksperimen diperoleh L- hitung masing-masing yaitu 0,04 dan 0,13 sedangkan $\mathrm{L}_{\text {tabel }}=0,220$. Berdasarkan kriteria $\mathrm{L}_{\text {hitung }}<\mathrm{L}_{\text {tabel }}$, maka data pre-test dan post-test kelas eksperimen terdistribusi normal.

Demikian juga untuk data pre-test dan post-test untuk kelas kontrol diperoleh $\mathrm{L}_{\text {hitung }}$ masing-masing yaitu 0,08 dan 0,10 sedangkan $\mathrm{L}_{\text {tabel }}=0,220$. Berdasarkan kriteria $\mathrm{L}_{\text {hitung }}<\mathrm{L}_{\text {tabel }}$, maka data pre-test dan post-test kelas kontrol terdistribusi normal. 
Tabel 8. Hasil Uji Normalitas Data Kelompok Eksperimen

\begin{tabular}{|c|c|c|c|c|c|}
\hline Kelas & Data & $\begin{array}{c}\text { Rata-rata } \\
\text { Standar Deviasi }\end{array}$ & $\mathbf{L}_{\text {hitung }}$ & $\mathbf{L}_{\text {tabel }}$ & Keterangan \\
\hline \multirow{3}{*}{ Eksperimen } & Pre-test & $\begin{array}{c}X=12,73 \\
\text { SD }=1,49\end{array}$ & 0,04 & 0,220 & $\begin{array}{c}\text { Data terdistribusi } \\
\text { normal }\end{array}$ \\
\cline { 2 - 6 } & Post-test & $\begin{array}{c}X=26,80 \\
\text { SD }=1,21\end{array}$ & 0,13 & 0,220 & $\begin{array}{c}\text { Data terdistribusi } \\
\text { normal }\end{array}$ \\
\hline
\end{tabular}

Tabel 9. Hasil Uji Normalitas Data Kelompok Kontrol

\begin{tabular}{|c|c|c|c|c|c|}
\hline Kelas & Data & $\begin{array}{c}\text { Rata-rata } \\
\text { Standar Deviasi }\end{array}$ & $\mathbf{L}_{\text {hitung }}$ & $\mathbf{L}_{\text {tabel }}$ & Keterangan \\
\hline \multirow{3}{*}{ Kontrol } & Pre-test & $\begin{array}{c}X=13,13 \\
\text { SD }=1.30\end{array}$ & 0,08 & 0,220 & $\begin{array}{c}\text { Data terdistribusi } \\
\text { normal }\end{array}$ \\
\cline { 2 - 6 } & Post-test & $\begin{array}{c}X=23,80 \\
\text { SD }=1,37\end{array}$ & 0,10 & 0,220 & $\begin{array}{c}\text { Data terdistribusi } \\
\text { normal }\end{array}$ \\
\hline
\end{tabular}

Berdasarkan tabel 11 dan tabel 12. Diatas dapat dilihat bahwa pada kedua kelas $\mathrm{L}_{\text {hitung }}<$ $\mathrm{L}_{\text {tabel }}$ sehingga dapat disimpulkan bahwa data pre-test dan post-test kedua kelas adalah terdistribusi normal pada taraf signifikan $(\alpha=0,05)$ dan $\mathrm{n}=15$

\section{Uji Homogenitas Data}

Dalam penelitian ini kriteria pengujian adalah jika $F_{\text {hitung }}<F_{\text {tabel }}$ maka data kedua kelas homogen. Data hasil pengujian disajikan pada tabel 13 dibawah ini.

Tabel 10. Hasil Uji Homogenitas Data

\begin{tabular}{|c|c|c|c|c|c|}
\hline Kelas & Data & Varians $\left(\mathbf{S}^{2}\right)$ & $\mathbf{F}_{\text {hitung }}$ & $\mathbf{F}_{\text {tabel }}$ & Keterangan \\
\hline Eksperimen & \multirow{2}{*}{ Hasil Belajar } & $\mathrm{S}^{2}=2,22$ & \multirow{2}{*}{1,31} & \multirow{2}{*}{2,48} & \multirow{2}{*}{ Homogen } \\
\cline { 1 - 1 } & & $\mathrm{S}^{2}=1,69$ & & \\
\hline
\end{tabular}

Bedasarkan tabel diatas dapat dilihat bahwa $\mathrm{F}_{\text {hitung }}<\mathrm{F}_{\text {tabel }}(1,31<2,48)$ maka dapat disimpulkan bahwa test hasil latihan kelas adalah homogen pada taraf signifikan $(\alpha=$ $0,05)$ dan $n=15$.

\section{Uji Hipotesis}

Uji hipostesis dengan menggunakan uji statistik uji-t dua pihak.Uji ini dilakukan untuk mengetahui apakah hipotesis dalam penelitian ini diterima atau ditolak. Kriteria pengujian jika $t_{\text {hitung }} \leq t_{\text {tabel }}$ maka hipotesis alternatif (Ha) ditolak dan hipotesis nihil (Ho) diterima. Data hasil hipotesis seperti pada tabel 14 Dibawah ini.

Bedasarkan tabel diatas dapat dilihat bahwa $\mathrm{F}_{\text {hitung }}<\mathrm{F}_{\text {tabel }}(1,31<2,48)$ maka dapat disimpulkan

Tabel 11 Hasil Uji Hipotesis

\begin{tabular}{|c|c|c|c|}
\hline Data & $\mathbf{t}_{\text {hitung }}$ & $\mathbf{t}_{\text {tabel }}$ & Keterangan \\
\hline Hasil Latihan & 6,25 & 1,70 & $($ Ha) diterima, (Ho) ditolak \\
\hline
\end{tabular}

\section{Pembahasan Hasil Penelitian Pengembangan Produk}

Produk pengembangan media video pembelajaran merupakan materi pembelajaran yang telah dikembangkan dengan memperhatikan aspek pembelajaran dan media sebagai prinsip desain pesan pembelajaran. Penelitian pengembangan produk yang dilakukan ini diarahkan untuk menghasilkan suatu produk berupa media video pembelajaran untuk atlet Tarung Derajat, yang digunakan untuk meningkatkan proses pembelajaran maupun kompetensi atlet. Karena itu dalam proses penelitian ini dilakukan dengan diawali studi pendahuluan, kemudian mendesain media pembelajaran, melakukan validasi produk dan 
melakukan revisi dan penyempurnaan berdasarkan analisis data validasi dari ahli materi, ahli desain pembelajaran dan ahli perangkat lunak yang dilanjutkan dengan uji coba perorangan, uji coba kelompok kecil dan uji coba lapangan sehingga dihasilkan media video pembelajaran yang layak digunakan sesuai karakteristik atlet sebagai pengguna.

Aspek yang direvisi dan disempurnakan berdasarkan analisis data dan uji coba serta masukan dari ahli materi, ahli desain pembelajaran, ahli perangkat lunak dan atlet selaku pengguna media video pembelajaran ini, bertujuan untuk menggali beberapa aspek yang lazim dalam proses pengembangan suatu produk. Variabel-variabel media video pembelajaran memiliki nilai rata-rata sangat baik. Adapun media video pembelajaran yang dinilai meliputi kelayakan isi, penyajian, kebahasaan, pemrograman, dan kegrafikan.

Manfaat yang diperoleh dari penggunaan media video pembelajaran adalah konsep yang disajikan mudah dipelajari, dipahami dan sistematis. Media video pembelajaran memberi kesempatan kepada atlet untuk belajar sesuai dengan kecepatan masingmasing, belajar lebih cepat dan tidak menimbulkan kebosanan karena dilengkapi dengan gambar-gambar dan animasi serta latihan yang bervariasi. Adanya pengulangan yang harus dilakukan saat gerakan salah menjadikan atlet lebih memahami materi dan bersikap hati-hati dalam melakukan gerakan. Media video pembelajaran ini juga dapat digunakan sebagai alternatif media video pembelajaran secara klasikal maupun individu.

\section{Pembahasan Hasil Penelitian Uji Efektifitas Produk}

Berdasarkan uji efektifitas produk yang menggunakan rumus perhitungan efektifitas (Sugiyono 2008:305), hasil pengolahan data penelitian yang dilakukan, terdapat perbedaan hasil latihan Tarung Derajat , antara atlet yang dibelajarkan dengan menggunakan media video pembelajaran dan atlet yang dibelajarkan dengan menggunakan media konvensional yaitu rata-rata hasil latihan atlet yang dibelajarkan dengan menggunakan media video pembelajaran lebih tinggi dibandingkan dengan atlet yang dibelajarkan dengan menggunakan media konvensional. Hal ini sejalan dengan pendapat Hannafi dan Peck dalam (Benny, 2005:32) bahwa potensi media video dapat dimanfaatkan untuk meningkatkan efektivitas proses pembelajaran,dapat dilihat dari nilai ratarata hasil latihan Tarung Derajat atlet yang diajar dengan media video pembelajaran yaitu sebesar $67 \%$, sedangkan hasil nilai rata-rata yang diajarkan dengan menggunakan media konvensional sebesar 59,50\%. Dari data ini membuktikan bahwa penggunaan media video pembelajaran lebih baik dalam meningkatkan pengetahuan atlet dalam latihan daripada penggunaan media konvensional. Atlet dapat mengerjakan latihan yang telah dilengkapi dengan balikan dan pembahasan sehingga atlet dapat mengetahui kesalahan yang telah dilakukan dalam mengerjakan latihan tersebut. Media video pembelajaran juga dilengkapi dengan rangkuman yang dapat membantu atlet memperoleh ringkasan materi pembelajaran yang dipaparkan.

Pembelajaran dengan media video juga memungkinkan pelatih bebas melakukan interaksi dengan atlet sehingga pembelajaran tersebut bersifat interaktif yang membuat pembelajaran terfokus pada informasi yang sedang dipelajari. Hal ini berbeda dengan pembelajaran menggunakan media konvensional, atlet tidak berinteraksi langsung pada sumber belajar, dan pembelajaran didominasi oleh pelatih yang menyajikan informasi secara linier atau satu arah. Hal ini terjadi karena atlet mendapatkan sumber informasi hanya dari pelatih dan materi-materi yang ada pada interaktif tanpa bisa memperoleh balikan dari latihan yang dikerjakan. Pembelajaran dengan menggunakan media video pembelajaran menempatkan pelatih menggunakan kontrol pembelajaran yang aktif, sementara atlet relatif pasif menerima dan mengikuti apa yang disampaikan pelatih. Pelatih menyampaikan materi secara terstruktur dengan harapan materi pembelajaran yang disampaikan dapat dikuasai dengan baik, dengan terfokus kepada kompetensi yang hendak dicapai.

Meski dalam penelitian ini diperoleh data bahwa hasil latihan atlet lebih dibelajarkan dengan media video pembelajaran daripada hasil latihan atlet yang dibelajarkan dengan media konvensional, namun dalam pelaksanaannya kedua media pembelajaran ini telah mampu meningkatkan pemahaman dan hasil latihan atlet. Keefektifan penggunaan media video pembelajaran adalah sebesar $67 \%$ dan konvensional sebesar 59,50\%. 


\section{PENUTUP}

Berdasarkan rumusan, tujuan, hasil dan pembahasan penelitian pengembangan media video pembelajaran yang dikemukakan sebelumnya, maka dapat disimpulkan sebagai berikut:

a) Berdasarkan tahapan validasi ahli materi, ahli desain, ahli perangkat lunak dan uji perorangan, uji kelompok kecil, serta uji lapangan dapat disimpulkan bahwa media video pembelajaran dinyatakan baik secara produk serta layak digunakan pada atlet Tarung Derajat Satuan latihan (Satlat ) Kampus II TPI Medan.

b) Efektifitas media video pembelajaran yang dikembangkan lebih efektif dibandingkan media konvensional yang digunakan pada latihan Tarung Derajat di Satlat Kampus II TPI Medan.

\section{DAFTAR PUSTAKA}

AECT, (1977). The Defenition of Educational Technology, Washington: Association for Educational Communication and Technology

Aqib, Z. (2010). Profesionalisme Guru dalam Pembelajaran. Surabaya: Insan Cendekia.

Borg, W.R \& M.D. Gall. (1983). Educational Research: An Introduction, New York: Longman, Inc

Cangara, Hafied. (2009). Komunikasi Politik:

Konsep, Teori dan Strategi. Jakarta: Rajawali

Pers

Dick, W. \& Carey, L. (2005). The Systematic Design of Instruction. United States of America: Scott Foresman and Company.

Gerlach dan Ely (1980). Teaching \& Media: A Systematic Approach. Second Edition, by V.S.Gerlach \& D.P. Boston, MA: Allyn and Bacon. Copyright 1980 by Pearson Education
Lingin. (2012). Pengembangan Media Pembelajaran Interaktif Pada Mata Pelajaran Geografi. Tesis. Program Pasca Sarjana Universitas Negeri Medan.

Miarso, Y. (2009). Menyemai Benih Teknologi Pendidikan. Jakarta: Kencana Prenada Media Group

Mursid, R. (2010). Pengembangan Model Pengembangan Praktik Berbasis Kompetensi Berorientasi Produksi Pada Pendidikan Teknik Mesin. Disertasi. Program Pasca Sarjana Universitas Negeri Jakarta.

Poerwadarminta, WJS. (2002). Kamus Umum Bahasa Indonesia. Jakarta: Balai Pustaka.

Pribadi, A. Benny. (2010)."Model Desain Sistem Pembelajaran"Jakarta: Dian Aksara.

Sahid, (2010), Pengembangan Media Pembelajaran berbsis ICT(Information communication and Technology), UNY

Sanjaya Wina. (2012). Perencanaan dan Desaian Sistem Pembelajaran. Jakarta. Kencana Prenada Media Group.

Seels, Barbara B. Richey, Rita C. (1994). Instructional Technology: The Definition and Domains Field. Washington. AECT.

Smaldino, S. E., dkk. 2011. Instructional Technology \& Media for Learning: Teknologi Pembelajaran dan Media untuk Belajar. Jakarta: Kencana.

Smaldino, Sharon E., et. al., (2012). Teknologi Pembelajaran dan Media Untuk Belajar Edisi Kesembilan. Jakarta, Kencana, p. 148.

Sugiyono. (2007). Metode Penelitian Pendidikan. Bandung: Alfabeta.

Sugiyono. (2010). Metode Penelitian Kuantitatif, Kualitatif, $R \& D$. Bandung: Alfabeta 